7. Monitorynh sotsialno-ekonomichnoho rozvytku rehioniv za sichen-hruden 2020 roku. 2021. Ministerstvo rozvytku hromad ta terytorii Ukrainy, Dyrektorat rehionalnoi polityky. URL: https://www.minregion.gov.ua/wpcontent/uploads/2021/03/rejtyngova-oczinka-za-sichen-gruden-2020-roku.pdf

8. Politolohichnyi slovnyk: navch. posib. dlia stud. vyshch. navch. zakl. / za red. M.F. Holovatoho ta O.F. Antoniuka. K.: MAUP, 2005. 792 p.

9. Politolohiia: navchalnyi entsyklopedychnyi slovnyk dovidnyk / Za nauk. red. d-ra polit. n. Khomy N. M. [V. M. Denysenko, O. M. Sorba, L. Ya. Uhryn ta in.]. Lviv: «Novyi Svit-2000», 2014. 778 p.

10. Posibnyk $\mathrm{z}$ informuvannia ta zaluchennia meshkantsiv u robotu TsNAP. 2019. URL: https://tsnap.ulead.org.ua/wp-content/uploads/2019/07/Posibnyk-z-informuvannya-ta-zaluchennya.pdf

11. Sait Kryvoozerskoi selyshchnoi rady. URL: https://krivoeozero-decentralization.gov.ua/?fbclid= IwAR26FBy5m_jwrjGMIQ4aN-q7Eqg02dwnyBXwic6voDjTtYW2Sx2Y5QsGm38

12. Frolova, N. Osoblyvosti vykorystannia sotsialnykh merezh u diialnosti orhaniv publichnoi vlady. Publichne administruvannia: teoriia ta praktyka, 2019, Vyp. 1 (21). URL: http://nbuv.gov.ua/UJRN/Patp_2019_1_12.

13. Shturkhetskyi, S. Rozvytok komunikatyvnykh stratehii v mistsevomu samovriaduvanni v Ukraini. Naukovi rozvidky z derzhavnoho ta munitsypalnoho upravlinnia. 2013, № 1. p. 269-283.

14. Facebook - naipopuliarnisha sotsmerezha ukraintsiv, za neiu ydut Instagram i Telegram - doslidzhennia. URL: https://ms.detector.media/sotsmerezhi/post/25606/2020-09-29-facebook-naypopulyarnisha-sotsmerezha-ukraintsivza-neyu-ydut-instagram-i-telegram-doslidzhennya/

15. GROMADA.INFO: informatsino-dovidkovyi portal OMS Ukrainy.

URL: https://gromada.info/gromada/krivoozerska/

DOI 10.31558/2617-0248.2021.6.10

удК 316.444.3(477)

\title{
СОЦІАЛЬНІ ЛІФТИ ЯК МЕХАНІЗМ РЕАЛІЗАЦЇ̈ ДЕРЖАВНОЇ МОЛОДІЖНОЇ ПОЛІТИКИ
}

ORCID ID: https://orcid.org/0000-0002-3380-7850

Кривошеїн В. В., А. політ. н., професор, завідувач кафедри Дніпровського національного університету імені Олеся Гончара

ORCID ID: https://orcid.org/0000-0001-5769-7345

Примуш М. В., А. політ. н., професор Донецького національного університету імені Василя Стуса

Метою даної статті $€$ характеристика функціонування соціальних ліфтів як одного із дієвих механізмів реалізації державної молодіжної політики. Визначено, що в умовах переходу до постіндустріальної фази цивілізаційного розвитку основною метою реалізації державної молодіжної політики в Україні має бути: створення умов для самореалізації кожної молодої людини та розвиток ініціатив молоді на принципах відкритості, системності та комплексності шляхом відновлення та покращення дії у суспільстві соціальних ліфтів. При цьому мають зберігатися вертикальні (традиційні) соціальні ліфти, пов'язані з ієрархічною структурою суспільства, та горизонтальні соціальні ліфти, створені із використанням інформаційно-комунікативних мереж і віртуальних середовищ. Продемонстровано, що державна молодіжна політика має бути орієнтована на створення і вдосконалення правових, соціально-економічних, науково-дослідницьких, організаційних умов успішної соціалізації $\mathrm{i}$ самореалізації української молоді, використання її творчого потенціалу в інтересах розвитку суспільства. Розкрито, що у державній молодіжній політиці необхідно враховувати такі основні стратифікуючі чинники: економічний добробут (дохід, багатство, власність), що грунтується на показниках середньо-осібного грошового доходу в системі «багатий - бідний»; маргіналізація значної частини населення, яка викликана значною спадаючою мобільністю в умовах загальної кризи й радикальних реформ, набуває переважно змушений характер під впливом зовнішніх факторів, пов'язаних із соціально-економічною й соціокультурною трансформацією суспільства в цілому; падіння значення освіти як фактору висхідної мобільності, що обумовлено нерівністю в одержанні освітніх можливостей для малозабезпечених (низькодохідних) груп.

Ключові слова: соціальна мобільність, види, загальні закономірності, функції вертикальної соціальної мобільності, види, канали соціальних ліфтів, соціальний контроль, стратифікуючі фактори. 
Kryvoshein V. V., Prymush M. V. Social lifts as a mechanism for implementing state youth policy The purpose of this article is to characterize the functioning of social lifts as one of the effective mechanisms for implementing state youth policy. It is determined that in the transition to the postindustrial phase of civilization development the main goal of the state youth policy in Ukraine should be: creating conditions for self-realization of every young person and development of youth initiatives on the principles of openness, system and comprehensiveness by restoring and improving social lifts. At the same time, vertical (traditional) social lifts connected with the hierarchical structure of society and horizontal social lifts created with the use of information and communication networks and virtual environments should be preserved. It is demonstrated that the state youth policy should be focused on the creation and improvement of legal, socio-economic, research, organizational conditions for successful socialization and self-realization of Ukrainian youth, the use of their creative potential in the interests of society. It is revealed that in the state youth policy it is necessary to take into account the following main stratifying factors: economic well-being (income, wealth, property), which is based on the indicators of the average monetary income in the system "rich - poor" the marginalization of a large part of the population, caused by a significant declining mobility in the context of the general crisis and radical reforms, is mainly forced under the influence of external factors related to socio-economic and socio-cultural transformation of society as a whole; falling importance of education as a factor of upward mobility, due to inequality in obtaining educational opportunities for low-income groups.

Keywords: social mobility, types, general regularities, functions of vertical social mobility, types, channels of social lifts, social control, stratifying factors.

Постановка проблеми у загальному вигляді та іï зв'язок із важливими науковими чи практичними завданнями. Сучасна українська молодь за своїми життєвими пріоритетами, які формують світогляд та стають регуляторами поведінки, дуже відрізняється від попередників. Такі відмінності продиктовані викликами сьогодення. Молодому фахівцю необхідно володіти великим обсягом постійно оновлюваної інформації, встигати за стрімким розвитком технологій, уміти вчитися самостійно та протягом усього життя. Саме такі соціально-політичні й економічні умови у контексті перехідного процесу України зумовили появу характеристик, що виділяють сучасну молодь від інших поколінь. Держава, через свою молодіжну політику, покликана створювати необхідні умови для зміцнення гарантій забезпечення прав i свобод молодих громадян, надавати допомогу в реалізації і самореалізації їх творчих можливостей та ініціатив, залучати молодь до активної участі в економічному та соціально-культурному розвитку суспільства. Відповідно, державна молодіжна політика повинна забезпечити рівні можливості для розкриття творчого, професійного, інтелектуального потенціалу молоді, набуття нею соціального досвіду та вміння жити в громадянському суспільстві, повинна вимагати більш активного втілення в життя задекларованих положень, тобто підкріплення конкретними практичними діями, які були б відчутні в молодіжному середовищі [6, с. 88].

Отже, як справедливо стверджує Михайло Обіход, метою ефективної реалізації державної молодіжної політики має бути «створення умов для формування суспільно активної і національно свідомої молоді шляхом відновлення та покращення дії у суспільстві соціальних “ліфтів”, піднесення ефективності такої політики, створення і вдосконалення правових, соціально-економічних, науково-дослідницьких, організаційних умов успішної соціалізації і самореалізації української молоді, використання ії творчого потенціалу в інтересах розвитку суспільства $[13$, с. 160]. Тобто державна молодіжна політика має відкривати для молоді соціальні ліфти.

Формулювання мети статті (постановка завдання). Метою даної статті $\epsilon$ характеристика функціонування соціальних ліфтів як одного із дієвих механізмів реалізації державної молодіжної політики.

Аналіз останніх досліджень і публікацій, в яких започатковано розв'язання даної проблеми i на які спирається автор. У науковій літературі розгляд даної тематики започатковано П. Сорокіним, який, зокрема, виділено вісім соціальних ліфтів: армія, церква, школа (освіта), політика, мистецтво, засоби масової інформації, бізнес, сім'я (див.: [20]). Серед зарубіжних авторів до проблеми соціальної мобільності, включаючи і соціальні ліфти, зверталися Рейнхард Бендікс [18], Ентоні Гідденс [4], Сеймур Ліпсет [18], Толкотт Парсонс [19] та ін. Ця проблема активно досліджувалася такими українськими авторами, як Ірина Герасимова [3], Микола Дроботенко [7-8], Наталія Коваліско [9-10], Свгенія Крашевська [11], Ігор Кудінов [11], Наталія Ніколаєнко [5], Валерій Новіков [12], Надія Попадюк [14], Ольга Птахіна [15], Таїсія Ратушна [11], Оксана Сенюра [9; 16], Валентина Фрицюк [3] та інші.

Виділення невирішених раніше частин загальної проблеми, котрим присвячується стаття. Отже, у вітчизняному науковому дискурсі проблема соціальних ліфтів здебільшого розглядалася в контексті елітобудування, підготовки фахівців, зокрема, в сфері публічного управління, соціального структурування та соціалізації. В умовах міжгенераційної трансформації забезпечення належного функціонування соціальних ліфтів є ключовим напрямом сучасної державної молодіжної політики і потребує поглибленого осмислення крізь призму методології соціального пізнання. 
Виклад основного матеріалу дослідження 3 повним обгрунтуванням отриманих результатів. Проблема соціального ліфту пов'язана із соціальною мобільністю. За визначенням відомого американського соціолога російського походження Пітіріма Сорокіна, соціальна мобільність - це переміщення індивідів всередині соціального простору, будь-який перехід індивіда або соціального об'єкта (цінності), тобто всього того, що створено або модифіковане людською діяльністю, з однієї соціальної позиції до іншої [20, р. 292]. Він виокремлює два основні типи соціальної мобільності: горизонтальна й вертикальна [20, p. 292-298]. Соціальні ліфти здебільшого належать до вертикальної соціальної мобільності. Вертикальна мобільність існує в будь-якому суспільстві, а між соціальними прошарками повинні бути якісь шляхи, якими індивіди й групи переміщуються вгору або вниз із одного соціального прошарку в інший.

Залежно від напрямку вертикального переміщення розрізняють два види вертикальної мобільності: висхідна й спадна (тобто соціальний підйом або соціальний спуск). 3 цього приводу П. Сорокін пише: «Висхідні течії існують в двох основних формах: проникнення індивіда з нижнього шару в існуючий більш високий шар; або створення такими індивідами нової групи і проникнення всієї групи в більш високий шар на рівень із вже існуючими групами цього шару. Відповідно і спадні течії також мають дві форми: перша полягає в падінні індивіда з більш високої соціальної позиції на більш низьку, не руйнуючи при цьому вихідної групи, до якої він раніше належав, інша форма проявляється в деградації соціальної групи в цілому, в пониженні іiі рангу на тлі інших груп або в руйнуванні ії соціальної єдності. У першому випадку “падіння” нагадує нам людину, що впала з корабля, в другому - занурення у воду самого судна з усіма пасажирами на борту або аварії корабля, коли він розбивається вщент» [20, р. 292-293].

Загальні закономірності вертикальної соціальної мобільності в цілому такі:

- ніколи не існувало суспільства, соціальні прошарки якого були б абсолютно закриті або в яких була б відсутня вертикальна мобільність у трьох їі основних аспектах - політичному, економічному і професійному;

- ніколи не існувало суспільства, в якому вертикальна соціальна мобільність була б абсолютно вільною, а перехід з одного соціального прошарку в інший здійснювався би без усякого спротиву. Це означає, що усередині організованого (стратифікованого) суспільства функціонує своєрідне «сито», «яке просіює» індивідів і дозволяє деяким із них підніматися наверх, залишаючи інших на нижніх щаблях, навпаки;

- вертикальна соціальна мобільність змінюється від суспільства до суспільства й від одного історичного періоду до іншого, тобто має коливальний характер [20, р. 295-298].

Соціальний ліфт - це умовне найменування сукупності чинників, системи об'єктивних умов, принципів, вироблених громадськими інститутами й соціальними спільнотами, групами, закріплених у вигляді цілісної державної політики, що визначально впливають на формування вертикальної соціальної мобільності індивідів. Соціальний ліфт - це власне «механізм соціальної мобільності», що заохочує конкуренцію індивідів і забезпечує мобільному індивіду напрям «до гори». Іншими завданнями цього механізму є відбір кращих; «фільтр» або захист суспільства від непрофесіоналів; управління можливостями людини: у суспільстві- соціальними можливостями, у професійній діяльностіпрофесійними тощо [9, с. 80].

Соціальний ліфт - це суспільний механізм, який відповідальний за відбір у вищі верстви найбільш здібних осіб. У цілому соціальний ліфт виконує три функції:

- відбір найбільш соціально активних індивідів (підвищує діяльність еліти й, відповідно, усього суспільства);

- відбір у лави еліти найбільш здібних представників суспільства із нижчих верств (це сприяє призупиненню соціальних протестів);

- для людей цінністю стає позиція, яка веде до успіху [9, с. 80].

Часто соціальний ліфт визначають як спосіб піднятися й допомогти людині зайняти більш привілейоване становище в суспільстві. Рушійною силою дієвих соціальних ліфтів є зацікавлені сторони, якими є як держава, суспільство, що реалізують свою волю через інститути влади, соціальні інститути, так і сама людина, котра має до того ж розвинений комплекс професійно мобільних якостей.

Соціальні ліфти поділяють на два види: традиційний варіант, тобто функціонування соціальних ліфтів, яке пов'язане з ієрархічною структурою суспільства, та горизонтальні соціальні ліфти, створені із використанням інформаційно-комунікативних мереж і віртуальних середовищ. Саме у світі віртуальності людина здатна створювати й використовувати соціальні ліфти, які пізніше можна запровадити в реалії суспільства (див.: [17]).

Основними каналами соціальної циркуляції («ліфтами») є: освіта, армія, церква, політика, мистецтво, засоби масової інформації, бізнес і сім’я, а також державна служба, громадська діяльність, спорт, шоу-бізнес.

Усередині стратифікованого суспільства існують не тільки канали вертикальної циркуляції («ліфти»), а й «сито», яке «просіює» індивідів і визначає їм відповідне місце в суспільстві. Основною метою цього соціального контролю є розподіл індивідів відповідно до їх здібності успішно виконувати соціальні функції, однак, це не означає, що зазначений соціальний механізм завжди правильно розподіляє індивідів відповідно до їхніх можливостей [20, p. 78]. 
До соціальних механізмів тестування, селекції й розподілу (тобто до соціального «сита» або «фільтру») належать ті ж суспільні інститути, які виконують, крім іншої, роль соціальних ліфтів. При цьому, як зауважує Оксана Болотська, «сім'я, церква і школа $\epsilon$ інституціональними механізмами, які перевіряють насамперед загальні здібності індивідів (психобіологічні, інтелектуальні й моральні якості), необхідні для успішного виконання спільних соціальних функцій. Інші інститути (як от політичні, економічні та професійні організації) $\epsilon$ соціальними механізмами, які тестують і селекціонують спеціальні здібності індивідів, необхідні для успішного виконання спеціальних функцій у певній галузі людської діяльності» [1].

У цілому, як зазначають Ю. Годован і Н. Ніколаєнко, «соціальна мобільність молоді в сьогоднішніх умовах виступає в Україні запорукою для майбутніх демократичних перетворень, створення комфортних умов для розвитку молодої особистості, формування в неї громадянської свідомості, й залученні іiї до важливих соціальних, політичних, економічних, культурних процесів, які мають місце відбуватись в суспільстві» [5, с. 78].

У державній молодіжній політиці необхідно враховувати зміни, що відбуваються у суспільстві, а саме: виникають нові системи соціальної диференціації, що змінюють мотивацію діяльності й можливість економічних досягнень практично всіх категорій населення. Радикальні зміни відносин власності й влади привели до формування нової шкали рівності-нерівності в соціальній організації суспільства. Основною тенденцією тут є поглиблення соціальної нерівності. Внаслідок цього постає питання про виділення основного стратифікуючого фактору, що діє як об'єктивно, так і через визнання його таким у свідомості людей.

Безумовно, основним стратифікуючим фактором в Україні $\epsilon$ економічний (дохід, багатство, власність), що грунтується на показниках середньоосібного грошового доходу в системі «багатий - бідний». Так, станом початок XXI ст. в Україні співвідношення між грошовими доходами $10 \%$ найбільш забезпечених і $10 \%$ найменш забезпечених груп населення перевищує 12 разів, тоді як у більшості високо розвинутих країнах світу цей коефіцієнт значно менший, наприклад, у Німеччині доходи 10 \% найбагатших перевищують доходи $10 \%$ найбідніших у 6,9 рази, Канаді та Японії - у 3,7 рази, а в Швеції він $\epsilon$ найнижчим і становить 2,7 рази (див.: [2]). Очевидно, що таке співвідношення зберігається і до сьогодні.

Іншим основним стратифікуючим фактором є маргіналізація значної частини населення, тобто проміжний стан людини або групи між іншими людьми, групами, яке виникає внаслідок втрати органічного зв'язку зі сталою системою відносин, з споконвічно природнім соціокультурним середовищем. Відмінною рисою маргінальності в Україні $\epsilon$, по-перше, те, що вона викликана значною спадаючою мобільністю в умовах загальної кризи й радикальних реформ, і по-друге, вона носить переважно змушений характер під впливом зовнішніх факторів, пов'язаних із соціально-економічною й соціокультурною трансформацією суспільства в цілому, яка, в свою чергу, призвела до зміни або повної втратити пов'язаного з ним соціального середовища, соціальних зв'язків й системи ціннісних орієнтацій соціальних групи, які раніше мали високий статус.

Освіта як канал соціального ліфту для молоді все більше втрачає цінність й усе більше стає метою для одержання високого статку в майбутньому. 3 одного боку, молодь цінує хорошу «грошову» роботу, а з іншого боку - освіта й професія мають інструментальну цінність як засіб досягнення матеріального благополуччя. Така прагматизація освіти приводить до орієнтації закладів освіти винятково на професійну підготовку й відмову від таких важливих аспектів змісту освіти, як виховання й соціалізація. Це виносить за рамки освіти такі актуальні для суспільства, яке трансформується, процеси, як вироблення прийнятної для більшості українців нової системи цінностей, формування соціальних норм, спрямованих на затвердження цих цінностей, і в першу чергу соціального партнерства різних статусних груп. Іншою стороною, що визначає падіння значення освіти як фактору висхідної мобільності, стає нерівність в одержанні освітніх можливостей для низькодохідних груп. Соціальна диференціація відбувається вже на рівні середньої школи, коли збільшення обсягу платних послуг з одного боку, і ріст числа ліцеїв і коледжів, які надають освітні послуги на комерційній основі, з іншої, виводять за рамки змагання за якісну освіту молодь із малозабезпечених родин технічної інтелігенції, традиційно орієнтованих на вищу освіту [1].

На нашу думку, у державній молодіжній політиці мають бути запроваджені дієві заходи профілактики деформації системи соціальних ліфтів. Основними напрямами такої роботи у сфері освіти $є$ такі:

- освіта має бути постійно діючим чинником протягом усього життя людини (причому пріоритет повинен віддаватися підвищенню та розширенню людиною вже освоєної раніше кваліфікації, а не безкінечним множенням їхньої кількості);

- освіта має бути доступною для всіх дійсно бажаючих (що обов'язково вимагає вибудовування різнорівневої системи тривалого накопичення «показників успішності» в певній сфері діяльності: навчальній, соціальній тощо, яка переходить із одного рівня освіти на інший);

- освіта має охоплювати не тільки розповсюджені сьогодні групи («талановиту молодь» тощо), а й передбачати варіанти для цільових груп, які не на сьогодні елітними; розширювати соціальні позиції, розповсюджені в суспільстві (робітничі професії, соціальна сфера, благодійність), зробивши їх привабливими просторами соціальної мобільності.

В Україні для представників малозабезпечених (низькодохідних) верств, навіть для тих, хто має високий рівень освіти, професійної підготовки й соціальної активності, використання цих ліфтів $\epsilon$ 
надзвичайно проблематичним. Тенденцією розвитку системи вищої освіти в Україні є збільшення питомої ваги в ній платної освіти. Наростання тенденції платності різко зменшує можливості одного 3 головних каналів соціальної мобільності, яка в сучасних умовах України спрямована не лише на перехід до вищої страти, а й на те, щоб вирватися із вимушеного перебування в маргінальному прошарку. Низка досліджень засвідчує, що на сьогодні можна говорити про формування так званого «соціального тромбу»: наявні соціальні ліфти або обмежені надзвичайно вузькими соціальними угрупованнями (наприклад, відмінне навчання чи перемога в олімпіадах можуть підняти шанси випускника школи на позаконкурсний вступ у престижний виш), або початково мають обмежену висоту «підйому» (наприклад, боєць загону за період навчання у виші може стати бригадиром).

Висновки i перспективи подальших розвідок уданому напрямку. В умовах переходу до постіндустріальної фази цивілізаційного розвитку молодій людині конче потрібно володіти великим обсягом постійно оновлюваної інформації, встигати за стрімким розвитком технологій, уміти вчитися самостійно та протягом усього життя. Тому основною метою реалізації державної молодіжної політики в Україні має бути: створення умов для самореалізації кожної молодої людини та розвиток ініціатив молоді на принципах відкритості, системності та комплексності, що особливо стосується поглиблення соціальної політики та підвищення якості життя. Державна молодіжна політика має бути спрямована на створення умов для формування суспільно активної і національно свідомої молоді шляхом відновлення та покращення дії у суспільстві соціальних ліфтів. При цьому в сучасних умовах мають зберігатися обидва види соціальних ліфтів - вертикальні (традиційні) соціальні ліфти, пов’язані з ієрархічною структурою суспільства, та горизонтальні соціальні ліфти, створені із використанням інформаційно-комунікативних мереж i віртуальних середовищ. У цілому державна молодіжна політика має бути орієнтована на створення i вдосконалення правових, соціально-економічних, науково-дослідницьких, організаційних умов успішної соціалізації і самореалізації української молоді, використання їі творчого потенціалу в інтересах розвитку суспільства.

Також у державній молодіжній політиці необхідно враховувати зміни, що відбуваються у суспільстві. Зокрема, реалізуючи державну молодіжну політику варто враховувати такі основні стратифікуючі чинники: економічний добробут (дохід, багатство, власність), що грунтується на показниках середньо-осібного грошового доходу в системі «багатий - бідний»; маргіналізація значної частини населення, яка викликана значною спадаючою мобільністю в умовах загальної кризи й радикальних реформ, набуває переважно змушений характер під впливом зовнішніх факторів, пов'язаних із соціально-економічною й соціокультурною трансформацією суспільства в цілому; падіння значення освіти як фактору висхідної мобільності, що обумовлено нерівністю в одержанні освітніх можливостей для малозабезпечених (низькодохідних) груп.

\section{Бібліографічний список:}

1. Болотська О. А. Чинники соціальної мобільності сучасної молоді в контексті реформування системи вищої освіти. Науковий вісник Донбасу. 2012. № 4. URL: http://www.irbis-nbuv.gov.ua/cgibin/irbis_nbuv/cgiirbis_64.exe?I21DBN=LINK\&P21DBN=UJRN\&Z21ID=\&S21REF=10\&S21CNR=20\&S21STN=1

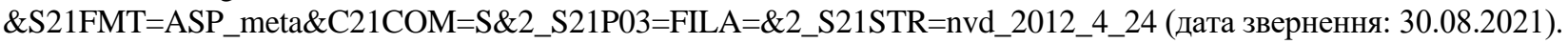

2. Волинський Г. Про соціальну диференціацію населення. Економіка України. 2008. № 2. С. $79-84$.

3. Герасимова I., Фрицюк В. Становлення феномена «професійна мобільність». Актуальні питання гуманітарних наук. 2020. Вип. 27 (1). С. 270-274.

4. Гідденс Е. Соціологія. Київ: Основи, 1999. 726 с.

5. Годован Ю. В., Ніколаєнко Н. О. Соціальна мобільність молоді як стратегічна складова політичної соціалізації молоді. Вісник Донецького національного університету імені Василя Стуса. Сер.: Політичні науки. 2017. С. 76-78.

6. Гуцалова М. В. Державна молодіжна політика як фактор залучення молоді до участі у державотворчих процесах. Наукові праці [Чорноморського державного університету імені Петра Могили комплексу «Києво-Могилянська академія»]. Серія: Державне управління. 2009. Т. 110, вип. 97. С. 85-88.

7. Дроботенко М. Проблема зміни еліт, або чи працюють «соціальні ліфти» для молоді? Украӥнознавчий альманах. 2013. Вип. 14. С. 103-106.

8. Дроботенко М. М. Соціальні ліфти для обдарованої молоді - як необхідність виховання і підготовки еліти нації. Освіта та розвиток обдарованої особистості. 2014. № 5. С. 20-23.

9. Коваліско Н. В., Сенюра О. В. Специфіка та механізми функціонування соціальних ліфтів у сучасному суспільстві. Актуальні проблеми філософї та соціологї: науково-практичний журнал. 2015. Вип. 6. С. 79-82.

10. Коваліско Н. Соціальний ліфт як чинник структурування сучасного українського суспільства. Український соиіологічний журнал. 2014. № 1-2. С. 59-64.

11. Крашевська С. В., Ратушна Т. О., Кудінов І. О. Державна служба як соціальний ліфт до регіональних еліт: у вимірі якісної соціології. Грані: науково-теоретичний альманах. 2019. Т. 22, № 8. С. 56-63.

12. Новіков В. М. Освіта як інструмент професійної і соціальної мобільності. Демографія та соціальна економіка. 2010. № 2. С. 26-35. 
13. Обіход М. Вдосконалення державного управління реалізацією молодіжної політики в Україні. Ефективність державного управління. 2017. Вип. 3 (52), ч. 1. С. 159-167.

14. Попадюк Н. І. «Соціальний ліфт» як механізм формування державно-управлінської еліти України. Науковий вісник Академії муніичиального управління. Серія: Управління. 2012. № 1. С. 296-304.

15. Птахіна О. М. Соціально-професійна мобільність фахівця як фактор професійної успішності. Вісник Луганського національного університету імені Тараса Шевченка. Педагогічні науки. 2018. № 6. C. 202-208.

16. Сенюра О. В. Соціальна мобільність у просторі великого міста: монографія. Львів: Видавництво Львівської політехніки, 2015. 216 с.

17. Castells M. The Information Age: Economy, Society and Culture. Vol. I. The Rise of the Network Society. Cambridge, Ma.; Oxford, UK: Blackwell, 1996. 556 p.; Vol. II. The Power of Identity. Cambridge, Ma.; Oxford, UK: Blackwell, 1997. 461 p.; Vol. III. End of Millennium. Cambridge, Ma.; Oxford, UK: Blackwell, 1998.418 p. $\mathrm{Xxi}, 309 \mathrm{p}$.

18. Lipset S. M., Bendix R. Social Mobility in Industrial Society. Berkeley: University California Press, 1959.

19. Parsons T. The Social System. New York: The Free Press, 1951. 575 p.

20. Sorokin P. A. Social and Cultural Mobility. New York: The Free Press, 1959. 645 p.

References:

1. Bolotska O. A. (2012) Chynnyky sotsialnoi mobilnosti suchasnoi molodi v konteksti reformuvannia systemy vyshchoi osvity. Naukovyi visnyk Donbasu. 4. URL: http://www.irbis-nbuv.gov.ua/cgi-bin/irbis_nbuv/ cgiirbis_64.exe?I21DBN=LINK\&P21DBN=UJRN\&Z21ID=\&S21REF=10\&S21CNR=20\&S21STN=1\&S21FMT= ASP_meta\&C21COM=S\&2_S21P03=FILA=\&2_S21STR=nvd_2012_4_24.

2. Volynskyi H. (2008) Pro sotsialnu dyferentsiatsiiu naselennia. Ekonomika Ukrainy. 2, 79-84.

3. Herasymova I., Frytsiuk V. (2020) Stanovlennia fenomena «profesiina mobilnist». Aktualni py-tannia humanitarnykh nauk. 27 (1), 270-274.

4. Hiddens E. (1999) Sotsiolohiia. Kyiv: Osnovy.

5. Hodovan Yu. V., Nikolaienko N. O. (2017) Sotsialna mobilnist molodi yak stratehichna skladova politychnoi sotsializatsii molodi. Visnyk Donetskoho natsionalnoho universytetu imeni Vasylia Stu-sa. Seriia: Politychni nauky. 76-78.

6. Hutsalova M. V. (2009) Derzhavna molodizhna polityka yak faktor zaluchennia molodi do uchasti u derzhavotvorchykh protsesakh. Naukovi pratsi [Chornomorskoho derzhavnoho universytetu imeni Petra Mohyly kompleksu «Kyievo-Mohylianska akademiia»]. Seriia: Derzhavne upravlinnia. 110 (97), 85-88.

7. Drobotenko M. (2013) Problema zminy elit, abo chy pratsiuiut «sotsialni lifty» dlia molodi? Ukrainoznavchyi almanakh. 14, 103-106.

8. Drobotenko M. M. (2014) Sotsialni lifty dlia obdarovanoi molodi- yak neobkhidnist vykhovannia i pidhotovky elity natsii. Osvita ta rozvytok obdarovanoi osobystosti. 5, 20-23.

9. Kovalisko N. V., Seniura O. V. (2015) Spetsyfika ta mekhanizmy funktsionuvannia sotsialnykh liftiv u suchasnomu suspilstvi. Aktualni problemy filosofii ta sotsiolohii: naukovo-praktychnyi zhurnal. 6, 79-82.

10. Kovalisko N. (2014) Sotsialnyi lift yak chynnyk strukturuvannia suchasnoho ukrainskoho suspilstva. Ukrainskyi sotsiolohichnyi zhurnal. 1-2, 59-64.

11. Krashevska Ye. V., Ratushna T. O., Kudinov I. O. (2019) Derzhavna sluzhba yak sotsialnyi lift do rehionalnykh elit: u vymiri yakisnoi sotsiolohii. Hrani: naukovo-teoretychnyi almanakh. 22 (8), 56-63.

12. Novikov V. M. (2010) Osvita yak instrument profesiinoi i sotsialnoi mobilnosti. Demohrafiia ta sotsialna ekonomika. 2, 26-35.

13. Obikhod M. (2017) Vdoskonalennia derzhavnoho upravlinnia realizatsiieiu molodizhnoi polityky v Ukraini. Efektyvnist derzhavnoho upravlinnia. 3 (1), 159-167.

14. Popadiuk N. I. (2012) «Sotsialnyi lift» yak mekhanizm formuvannia derzhavno-upravlinskoi elity Ukrainy. Naukovyi visnyk Akademii munitsypalnoho upravlinnia. Seriia: Upravlinnia. 1, 296-304.

15. Ptakhina O. M. (2018) Sotsialno-profesiina mobilnist fakhivtsia yak faktor profesiinoi uspishnosti. Visnyk Luhanskoho natsionalnoho universytetu imeni Tarasa Shevchenka. Pedahohichni nauky. 6, 202-208.

16. Seniura O. V. (2015) Sotsialna mobilnist u prostori velykoho mista: monohrafiia. Lviv: Vydavnytstvo Lvivskoi politekhniky.

17. Castells M. (1996-1998) The Information Age: Economy, Society and Culture. Cambridge, Ma.; Oxford, UK: Blackwell. Vol. I. The Rise of the Network Society; Vol. II. The Power of Identity; Vol. III. End of Millennium.

18. Lipset S. M., Bendix R. (1959) Social Mobility in Industrial Society. Berkeley: University California Press.

19. Parsons T. (1951) The Social System. New York: The Free Press.

20. Sorokin P. A. (1959) Social and Cultural Mobility. New York: The Free Press. 